\title{
Pengaruh Waktu Fertilisasi dan Sistem Inkubasi yang Berbeda terhadap Tingkat Fertilisasi Sapi Lokal Secara In Vitro
}

\section{The Effect of Fertilization Time and Different Incubation System on Fertilization Level of Indigenous Cow by In-Vitro}

\author{
F. L. Syaiful, R. Saladin, Jaswandi, dan Z, Udin \\ Fakultas Peternakan Universitas Andalas \\ Kampus Unand Limau Manis Padang 25153 \\ E-mail: ferrylismantonova@yahoo.com \\ (Diterima: 01 Desember 2010; Disetujui: 28 Januari 2011)
}

\begin{abstract}
The purpose of this study was to determine the effect of fertilization time and different incubation systems on fertilization level by in-vitro. The mature of ovaries from indigenous cow and fresh cement from Holstein Frisian cows (FH), 0.9\% NaCl physiological PBS, Nissui Japan, l, TCM-199, HEPES $30 \mu \mathrm{M}, 20$ $m L$ Heparin, $10 \%$ goat serum, $250 \mathrm{~g} / \mathrm{ml}$ FSH BO medium, medium gentamisain $50 \mathrm{mB}-O$, mineral oil, alcohol, aquabidest, and $1 \%$ aceto orcein were materials and reagents. The Completely Randomized Design (CRD) in factorial pattern was used. Results shown no significant effect on the percentage of fertilized oocytes and level of development of pronuclei $(2 P N$ and $>2 P N)$ by different timing of fertilization and incubation system. The development of pronucleus (IPN) showed significant $(P<0.05)$ on 12 hours $(37.60$ \%), but no significant effect on different incubation system. It concluded, the system of incubation and time of fertilization has no effect on oocyte fertilization rate. Oocytes fertilization time can be performed at 6 hours, 12 hours, and 18 hours, while the extension of the period of fertilization until 18 hours did not increase the level offertilization.
\end{abstract}

Keywords: Incubation systems, fertilization time, FIV and pronucleus

\section{PENDAHULUAN}

Teknologi fertilisasi in vitro (FIV) merupakan teknologi produksi embrio pada lingkungan buatan diluar tubuh dalam suatu sistem biakan sel (Hunter, 1995). Teknik fertilisasi in vitro (FIV) dapat menggunakan oosit yang berasal dari hewan yang masih hidup maupun dari oosit hewan yang dipotong, sehingga teknik fertilisasi in vitro (FIV) ini dapat menjadi alternatif produksi embrio dalam pelaksanaan transfer embrio (TE). Manfaat lain dari teknologi fertilisasi in vitro (FIV) adalah membuka peluang yang lebih besar untuk mengembangkan teknik manipulasi gamet dan embrio seperti produksi kloning (Gordon, 1994).

Penerapan bioteknologi ini membutuhkan oosit dalam jumlah yang banyak, selanjutnya oosit yang diperoleh dimatangkan secara in vitro (in vitro maturation) untuk kepentingan fertilisasi in vitro. Keberhasilan fertilisasi in vitro memerlukan kesiapan yang memadai dari oosit dan sperma secara biologis dan kondisi kultur yang mendukung efektifitas metabolis dari gamet jantan dan betina, Berbagai aspek kondisi kultur seperti medium, waktu inseminasi dan kapasitasi, sistem kultur terus di indentikasi untuk meningkatkan keberhasilan fertilisasi in vitro (Bracket dan Zuelke, 1993).

Menurut Herdis (2000), embrio yang dihasilkan dari teknologi fertilisasi in vitro dapat di transfer ke ternak resipien untuk membantu percepatan peningkatan populasi temak. Dengan teknik fertilisasi in vitro, pemanfaatan oosit dari hewan yang dipotong merupakan cara produksi embrio yang ekonomis karena dengan cara ini oosit hewan yang dipotong dapat dimanfaatkan untuk dijadikan bakal bibit, hal ini tentu akan terasa sekali nilai tambahnya. Dalam pemanfaatan oosit hewan yang mati belum semua potensi yang ada dapat dimanfaatkan karena terbatasnya daya hidup oosit, sementara teknologi penyimpanan ovarium yang dapat mempertahankan viabilitas oosit dalam waktu yang cukup lama atau selama transportasi belum tersedia.

Untuk meningkatkan fertilisasi dan fleksibilitas produksi embrio in vitro dapat dilakukan diluar laboratorium, beberapa penelitian mencoba untuk menggantikan sumber atau peranan $\mathrm{CO}_{2} 5 \%$ dalam mempertahankan $\mathrm{pH}$ medium. $\mathrm{PH}$ 
medium dapat dipertahankan dengan menambahkan suatu penyangga seperti Hepes. Menurut Jaswandi (2002), bahwa hasil pematangan dan fertilisasi in vitro oosit domba dengan penambahan penyangga Hepes dalam medium dapat memberikan kondisi optimal. Dengan demikian penggunaan straw perlu dikaitkan dengan penambahan penyangga Hepes dalam medium serta waktu inkubasi sehingga efek sinergis penggunaannya dapat dicapai secara optimal.

Komposisi gas udara merupakan salah satu faktor penting yang mempengaruhi perkembangan oosit embrio dalam inkubasi. Tingkat maturasi dan fertilisasi oosit serta pertumbuhan embrio terbaik diperoleh pada gas $\mathrm{CO}_{2}, 2,5-5 \%$ dan $\mathrm{O}_{2} 5 \%$ di udara (Pinyopummint dan Bavister, 1995). Sedangkan menurut Thompson (1996), perkembangan embrio sapi tidak mutlak tergantung terhadap $\mathrm{CO}_{2} 5 \%$ hal ini terlihat pada embrio sapi yang mampu berkembang sampai tahap blastosis bila medium ditambah dengan penyangga zwitter ionic pada udara tanpa $\mathrm{CO}_{2} 5 \%$. Freshney (1987) mengemukakan bahwa kultur sel dalam tempat terbuka membutuhkan inkubasi dengan $\mathrm{CO}_{2} 5 \%$ di udara.

Keadaan ini dapat dimanfaatkan sebagai dasar dalam manipulasi $\mathrm{CO}_{2} 5 \%$ pada sistem inkubasi. Proses fertilisasi in vitro pada sistim inkubasi tanpa gas $\mathrm{CO}_{2}$ dilapangan dirasakan sangatlah efisien dibandingkan sistem inkubasi $\mathrm{CO}_{2} 5 \%$ karena keterbatasan $\mathrm{CO}_{2}$ dilapangan sangat menghambat proses fertilisasi in vitro. Untuk itu diperlukan teknologi yang memungkinkan proses produksi embrio dapat dilakukan selama transportasi atau di luar laboratorium. Kendala utama dalam produksi embrio di luar laboratorium atau selama transportasi adalah keberadaan $\mathrm{CO}_{2}$ dan tempat fertilisasi. Oleh karena itu perlu dilakukan kajian mengenai penggunaan sistem inkubasi $\mathrm{CO}_{2}$ dan sistem inkubasi tanpa $\mathrm{CO}_{3}$ dan waktu fertilisasi yang tepat terhadap tingkat fertilisasi sapi in vitro.

Berdasarkan permasalahan diatas, penulis mengangakat kajian pada sebuah penelitian dengan judul "Pengaruh Waktu Fertilisasi dan Sistem Inkubasi Yang Berbeda Terhadap Tingkat Fertilisasi Sapi Lokal Secara In Vitro ". Penelitian ini bertujuan untuk mengetahui pengaruh waktu terhadap tingkat fertilisasi in vitro dan mendapatkan waktu/ periode terbaik fertilisasi in vitro.

\section{MATERI DAN METODE}

Penelitian ini dilaksanakan di Laboratorium Reproduksi Fakultas Peternakan Universitas Andalas Padang. Materi yang digunakan dalam penelitian ini adalah Ovarium sebagai sumber oosit diperoleh dari sapi lokal dewasa. Semen yang digunakan adalah semen segar sapi Frisian Holstein (FH) Bahan-bahan yang digunakan adalah $\mathrm{NaCl}$ fisiologis $0,9 \%$, Phosphate Buffered Salline (PBS; Nissui Jepang), Tissue Culture Medium- 199 (TCM-199; Sigma, M-5017), Hepes $30 \mu \mathrm{M}$ (Sigma; H-1617), Heparin $20 \mu \mathrm{l}$, Goat serwm $10 \%$, FSH $250 \mathrm{ml}$, Gentamisain (Sigma 6-1397) $50 \mathrm{mg} / \mathrm{ml}$, medium Brackett Oliphant (B-O), medium modifikasi Brackett Oliphant (mB-O), Mineral oil, Alkohol Aquabidest, dan Aceto Orcein 1\% (Sigma O7380). Alat-alat yang digunakan adalah Termos untuk tempat ovarium saat transportasi ke laboratorium, pisau silet untuk slicing ovarium, pipet pasteur, pipet eppendorf, inkubator, mikroskop stereo, mikroskop inverted, mikropipet $(50 \mu \mathrm{l}$ dan $250 \mu \mathrm{l})$, timbangan elektronik, cawan petri, straw $0,25 \mathrm{ml}$, pH meter, cover glass, objek glass, tissuc, aluminium foil dan vagina buatan untuk menampung semen.

\section{Rancangan percobaan}

Rancangan yang digunakan untuk pematangan (maturasi) oosit pada periode inkubasi 24 jam menggunakan Rancangan Acak Lengkap (RAL) dan data hasil fertilisasi dianalisis dengan Rancangan Acak Lengkap (RAL) pola faktorial $2 x$ 3. Setiap perlakuan terdiri atas tiga (3) ulangan, yang masing-masing unit percobaan terdiri atas 10 oosit. Adapun perlakuan tersebut adalah:

a. Faktor $I=$ Sistem inkubasi terdiri atas dua macam yaitu sistem inkubasi $\mathrm{CO}_{2} \quad 5 \%$ dan sistem inkubasi tanpa $\mathrm{CO}_{2} 5 \%$.

Fertilisasi pada 18 jam setelah maturasi.

b. Faktor II = Waktu fertilisasi terdiri atas tiga perlakuan yaitu:

P1 = Waktu fertilisasi pada 6 jam setelah maturasi.

P2 = Waktu fertilisasi pada 12 jam setelah maturasi.

P3 = Waktu fertilisasi pada 18 jam setelah maturasi 


\section{Prosedur penelitian}

Prosedur kerja yang dilakukan dalam penelitian ini adalah:

Koleksi oosit. Untuk koleksi oosit media dasar yang digunakan adalah Phosphate Buffered Salline (PBS), Media disterilkan dalam autoclove pada temperatur $120^{\circ} \mathrm{C}$ selama 30 menit dan setelah itu disimpan pada temperatur ruangan. Pada hari pengambilan ovarium, media dasar yang disupiementasi dengan $100 \mathrm{IU}$ pennicillin/ $\mathrm{ml}$ dan $100 \mu \mathrm{g}$ streptomicin/ ml. Untuk pematangan digurakan media TCM-199 ditambah dengan goat serum $10 \%$. Sterilisasi media ini dilakukan dengan menyaring menggunakan filter millipore $0,22 \mathrm{gm}$.

Ovarium yang diperoleh di Rumah Pemotongan Hewan (RPH) lalu dibawa ke laboratorium dengan termos yang berisi medium $\mathrm{NaCl}$ fisiologis $0,9 \%$ yang ditambahkan dengan steptomisin $100 \mu \mathrm{g} / \mathrm{ml}$ dan penisillin $100 \mathrm{IU} / \mathrm{ml}$ lalu disimpan dalam termos pada suhu $35^{\circ} \mathrm{C}$, kemudian ovarium yang diperoleh dicuci sampai bersih.

Oosit diperoleh dari ovarium sapi, untuk koleksi oosit dilakukan dengan metode penyayatan (slicing). Ovarium disayat dalam petridish yang berisi medium Phosphate Buffer Saline (PBS) yang disuplementasi dengan goat serum $10 \%$ dan gentamisin (Sigmu, G-1397) $50 \mu \mathrm{g} / \mathrm{ml}$. Jumlah dan kualitas oosit yang diperoleh diamati dibawah mikroskop. Oosit yang digunakan untuk maturasi adalahoosit kualitas Adan B.

Maturasi oosit. Oosit yang digunakan adalah oosit kualitas A dan B. Proseđur maturasi dilakukan menurut prosedur yang dikemukakan Jaswandi et al., (2003). Oosit kualitas Adan B tersebut lalu dicuci 3 kali dalam medium Phosphate Buffered Saline (PBS) selanjutnya oosit dimatangkan dalam medium pematangan (maturasi). Untuk pematangan pada sistem inkubasi $\mathrm{CO}_{2} 5 \%$, oosit dimatangkan dalam cawan petri pada medium TCM-199 yang disuplementasi dengan goat serum $10 \%, \mathrm{FSH}$ mg/ml dan gentamisin $50 \mathrm{mg} / \mathrm{ml}$. Pematangan pada cawan petri tersebut dibuat empat buah mikrodrop (droplet). Setiap mikrodrop (droplet) berisi $100 \mathrm{ml}$ medium pematangan TCM-199, kemudian dimasukkan 20 cosit ke dalam mikrodrop lalu dimasukan mineral oil ke dalam cawan petri tersebut.
Selanjutnya masing-masing dari cawan petri terscbut dimasukkan ke dalam inkubator $\mathrm{CO}_{2} 5 \%$, lalu di inkubasi pada suhu $38,5^{\circ} \mathrm{C}$ selama 24 jam.

Sedangkan untuk pematangan oosit pada sistem inkubasi tanpa $\mathrm{CO}_{2} 5 \%$ dilakukan dengan menggunakan straw $0,25 \mathrm{ml}$ pada medium TCM$199+$ Hepes $30 \mathrm{mM}$ yang disuplementasi dengan goat serum $10 \%$, FSH mg/ ml dan gentamisin 50 $\mathrm{mg} / \mathrm{ml}$. Kemudian cosit tersebut disedot kedalam straw dengan cara menempelkan spuit pada ujung straw yang mempunyai kapas. Oosit disedotkan ke dalam straw sebanyak 10-20 oosit/ straw. Oosit di dalam straw ditempatkan sedemikian rupa sebagaimana dengan penempatan semen beku seperti terlihat pada Gambar 1 .

Selanjutnya dilakukan maturasi oosit selama 24 jam pada kedua sistem inkubasi (sistem inkubasi $\mathrm{CO}_{2} 5 \%$ dan sistem inkubasi tanpa $\mathrm{CO}_{2} 5 \%$ ). setelah maturasi/ pematangan oosit lalu diamati status oosit tersebut dibawah mikroskop. Oosit yang telah mengalami metaphase-II (M-II) yang akan digunakan untuk difertilisasi.

Kapasitasi sperma. Sperma yang digunakan adalah sperma segar yang diambil dari sapi pejantan Frisian Holstein (FH) dengan bantuan vagina buatan. Prosedur peneucian sperma pada kapasitasi sperma dilakukan menurut prosedur Jaswandi et al. (2003), yaitu dengan menambahkan $4 \mathrm{mi}$ medium kapasitasi yaitu medium Brackett Oliphant (B-O) dan medium modifikasi Brackett Oliphant (mB-O) ke dalam tabung sentrifus yang berisi $200 \mu \mathrm{l}$ semen sapi, selanjutnya dilakukan disentrifugasi sclama 10 menit. Pada sistem inkubasi $\mathrm{CO}_{2} 5 \%$ menggunakan medium kapasitasi yaitu medium B-O sedangkan tampa $\mathrm{CO}_{2} 5 \%$ medium yang digunakan untuk kapasitasi sperma adalah medium mB-O. Selanjutnya di sentrifugasi $500 \mathrm{G}$ selama 10 menit. Bagian supernatan dari hasil setrifugasi tersebut dibuang, dan endapan sperma hasil pencucian diericerkan sampai konsentrasi $1 \times 10^{7}$ sperma/ $\mathrm{ml}$ dengan menggunakan medium perlakuan yaitu medium (B-O dan mB-O) yang disuplementasi dengan heparin (sigma, H-3125) $20 \mu \mathrm{l}$, goat serum $10 \%$ dan gentamisin $50 \mu \mathrm{g} / \mathrm{ml}$ lalu di inkubasi pada suhu $38,5^{\circ} \mathrm{C}$ selama 30 menit. 


\begin{tabular}{|l|c|c|c|c|c|}
\hline & & 0000000000 & & & \\
\hline Medium & Udara & Medium dan Oosit & Udara & Medium Kapas
\end{tabular}

Gambar 1. Oosit dalam straw

Fertilisasi in vitro oosit. Oosit yang telah matang baik pada kedua sistem inkubasi (sistem inkubasi $\mathrm{CO}_{2} 5 \%$ dan sistem inkubasi tanpa $\mathrm{CO}_{2} 5 \%$ ) masinng-masing oosit perlakuan tersebut dicuci tiga kali dengan medium fertilisasi (medium B-O dan medium mB-O) untuk membuang sebagian sel-sel kumulusnya. Sedangkan untuk perlakuan pada sistem inkubasi $\mathrm{CO}_{2} 5 \%$ menggunakan medium $\mathrm{B}-\mathrm{O}$ dan sistem inkubasi tanpa $\mathrm{CO} 25 \%$ menggunakan medium mB-O. PH medium modifikasi B-O (mBO) diatur dengan menambahkan $\mathrm{NaOH} 1 \mathrm{~N}$ sehingga mencapai $\mathrm{pH} \pm 7,4$. Pada sistem inkubasi dengan $\mathrm{CO}_{2} 5 \%$ dimasukkan 10-20 oosit ke dalam $50 \mu \mathrm{l}$ medium Brackett Oliphant (B-O) pada cawan petri lalu ditambahkan dengan $50 \mu \mathrm{l}$ semen dengan sperma yang telah mengalami kapasitasi sehingga konsentrasi akhir menjadi $1 \times 10^{\circ}$ sperma/ml. Sedangkan pada sistem inkubasi tanpa $\mathrm{CO}_{2} 5 \%$ oosit difertilisasi dalam straw. Sperma yang digunakan diencerkan sampai konsentrasi $1 \times 10^{6}$ sperma/ml dengan medium fertilisasi. Oosit dan sperma kemudian disedotkan ke dalam straw, setiap straw terdapat 10-20 oosit. Posisi dan penempatan oosit dalam straw sama dengan pada proses pematangan, seperti yang terlihat pada Gambar 1 .

Sedangkan fertilisasi oosit dilakukan selama 6,12 dan 18 jam yang di inkubasi pada suhu 38,5 ${ }^{\circ} \mathrm{C}$ pada masing-masing sistem inkubasi yang berbeda yaitu sistem inkubasi $\mathrm{CO}_{2} 5 \%$ dan sistem inkubasi tanpa $\mathrm{CO}_{1} 5 \%$.

Evaluasi fertilisasi in vitro. Untuk melihat tingkat fertilisasi dilakukan dengan cara mengamati perkembangan pronukleus ( $1 \mathrm{PN}, 2 \mathrm{PN}$ dan $>2 \mathrm{PN}$ ) dengan metode pewarnaan aceto orcein. Prosedur pewarnaan ini berdasarkan Jaswandi (2003). sebelum diwarnai terlebih dahulu oosit dibersihkan dari sel-sel kumulus dengan memipet beberapa kali dalam medium Phosphate Buffered Salline (PBS), kemudian difiksasi dalam larutan asam asetat dan larutan ctanol absolut dengan perbandingan (1:3) selama 48 jam kemudian diwarnai dengan pewamaan aceto orcein 1\% (Sigma, 0-7380) selama 10 menit, kemudian status inti oosit tersebut diamati dibawahmikroskop.

Oosit yang mempunyai satu pronukleus ( 1 PN) diasumsikan oosit hanya terdiri atas pronukleus betina, sedangkan oosit yang mempunyai dua pronuklei (2 PN) diasumsikan terdiri atas pronukleus jantan dan betina. Oosit yang mempunyai lebih dari dua pronuklei $(>2 \mathrm{PN})$ diasumsikan oosit terdiri atas dua atau lebih pronuklei betina dan satu pronukleus jantan, atau sebaliknya. Oosit dikategorikan terfertilisasi apabila mempunyai dua buah atau lebih pronuklei (2 PN dan $>2$ PN). Variabel yang diamati adalah: persentase fertilisasi in vitro dan ringkat perkembangan pronukleus (PN). Data hasil fertilisasi yang diperoleh dianalisis dengan Rancangan Acak Lengkap (RAL) pola faktorial $2 \mathrm{x}$ 3. Jika terdapat pengaruh yang nyata, maka analisis dilanjutkan dengan uji DMRT Duncan's Multiple Range Test(Steel dan Torrie, 1995).

\section{HASIL DAN PEMBAHASAN}

\section{Persentase fertilisasi in vitro}

Hasil Penelitian ini menunjukkan rataan persentase fertilisasi in vitro pada kedua sistem inkubasi yaitu sistem inkubasi $\mathrm{CO} 25 \%$ dan tanpa $\mathrm{CO} 25 \%$ pada ketiga periode inkubasi dapat terlihat pada Tabel 1.

Rataan persentase fertilisasí oosit pada waktu fertilisasi 6 jam adalah $63.63 \%, 12$ jam sebesar $56,31 \%$, dan 18 jam yaitu $62,12 \%$. Sedangkan rataan persentase fertilisasi oosit pada sistem inkubasi $\mathrm{Co}, 5 \%$ adalah $61,46 \%$ sedangkan tanpa $\mathrm{CO}_{3} 5 \%$ sebesar $59,60 \%$ seperti terlihat pada Tabel 1. Tetapi setelah dianalisis secara statistik, persentase fertilisasi oosit menunjukkan penambahan waktu fertilisasi tidak berpengaruh nyata $(\mathrm{P}>0,05)$ terhadap sistem inkubasi yang berbeda. 
Tabel 1. Persentase fertilisasi oosit sapi lokal pada waktu fertilisasi dan sistem inkubasi yang berbeda

\begin{tabular}{cccc}
\hline $\begin{array}{c}\text { Sistem Inkubasi } \\
(\%)\end{array}$ & $\begin{array}{c}\text { Waktu } \\
\text { Fertilisasi (jam) }\end{array}$ & $\begin{array}{c}\text { Jumlah Oosit } \\
\text { (buah) }\end{array}$ & Fertilisasi (\%) \\
\hline \multirow{2}{*}{ 1. Dengan $\mathrm{CO}_{2} 5$} & 6 & 35 & $23(65,71)$ \\
& 12 & 23 & $13(56,52)$ \\
\hline \multirow{2}{*}{ 2. Tanpa $\mathrm{CO}_{2} 5$} & 18 & 37 & $23(62,16)$ \\
& 6 & 26 & $16(61,54)$ \\
& 12 & 41 & $23(56,10)$ \\
& 18 & 29 & $18(62,07)$ \\
\hline
\end{tabular}

Persentase fertilisasi yang tidak berpengaruh nyata pada sistem inkubasi yang berbeda, hal ini disebabkan oleh adanya suplementasi hepes ke dalam medium mB-O pada sistem inkubasi $\mathrm{CO}_{2} 5 \%$ sebagai buffer dalam medium. Ditambah oleh Shamsuddin et al (1993), penambahan penyangga Hepes dalam medium serta waktu inkubasi sehingga efek sinergis penggunaannya dapat dicapai secara optimal. Diperkuat oleh Jaswandi (2002), tingkat maturasi oosit in vitro penggunaan Hepes 10-30 $\mathrm{mM}$ dalam medium cukup efektif pada kondisi tanpa $\mathrm{CO}_{2} 5 \%$ baik menggunakan cawan petri maupun straw. Hasil pematangan dan fertilisasi in vitro oosit domba dengan penambahan penyangga Hepes dalam medium dapat memberikan kondisi optimal.

Dari hasil penelitian, terlihat pada Gambar 2. tingkat fertilisasi dari ketiga waktu fertilisasi 6,12 dan 18 jam terhadap sistem inkubasi yang berbeda adalah hampir sama. Sedangkan persentase fertilisasi in vitro pada waktu fertilisasi 12 jam mengalami penurunan. Hal ini sesuai dengan penelitian Jaswandi (2002) bahwa tingkat fertilisasi cosit pada domba mengalami penurunan pada periode inkubasi 12 jam. Ditambahkan oleh Rehman et al (1994), bahwa fertilisasi pada sapi dengan perlakuan waktu inkubasi kurang dari 16 jam dengan tingkat fertilisasi sebesar $57,16 \%$.

Tingkat fertilisasi yang hampir sama diantara periode inkubasi disebabkan oosit mempunyai mekanisme yang menghambat masuknya sperma lain bila telah terjadinya penetrasi oleh satu sperma. Perpanjangan periode inkubasi sampai 18 jam tidak berpengaruh terhadap tingkat fertilisasi oosit. Menurut Hafez dan Hafez (2000) bahwa setelah terjadinya fertilisasi permukaan oosit mengalami perubahan untukmencegah fusi sperma lainnya.
Dari hasil penelitian ini menunjukkan bahwa periode inkubasi selama 6 jam telah memungkinkan bagi sperma untuk mempenetrasi cosit. Dode et al., (2002) melaporkan bahwa penetrasi oosit oleh sperma dirinkubasi selama 6 jam memperoleh tingkat penetrasi sperma 63,3\% Sedangkan Jiang (1991) memperolch tingkat monospermia dan polyspermia pada beberapa periode inkubasi setelah inseminasi sperma pada oosit sapi yang dimaturasi in vitro adalah sebagai berikut: monospermia pada periode inkubasi 6 jam $45,3 \% ; 12$ jam $68,6 \%$ dan 20 jam $80,9 \%$, sedangkan tingkat polyspermia adalah pada periode inkubasi 6 jam adalah $0,0 \% ; 12$ jam $9,8 \%$ sedangkan 20 jam $12,8 \%$.

Inkubasi oosit dan sperma yang terlalu lama dapat mengurangi kemampuan oosit berkembang karena sperma yang terlalu lama dapat mengurangi kemampuan oosit berkembang karena sperma mempunyai potensi untuk melepaskan enzim hidrolitik kedalam medium fertilisasi (Gordon, 1994). Hasil penelitian dari pengaruh perlakuan terhadap tingkat fertilisasi in vitro dari kedua sistem inkubasi pada 3 periode inkubasi dapat dilihat pada Gambar 3. Terlihat pada Gambar 3 tingkat perkembangan pronukleus (IPN) pada sistem inkubasi yang berbeda diperoleh yaitu untuk sistem inkubasi $\mathrm{CO}_{2} 5 \%$ yaitu $26,32 \%$ sedangkan peda sistem inkubasi tanpa $\mathrm{CO}_{2} 5 \%$ sebesar $28,13 \%$. Hasil analisis statistik menunjukkan bahwa tidak terdapat perbedaan pada IPN pada sistem inkubasi berbeda $(\mathrm{P}>0,05)$. Tingkat perkembangan yang hampir sama diantara kedua 5istem inkubasi dikarenakan pada penelitian ini disuplementasi Heparin dengan dosis $20 \mu \mathrm{g} / \mathrm{ml}$ ke dalam medium fertilisasi. Dari hasil penelitian $\mathrm{Lu}$ (1990), melaporkan bahwa penggunaan Heparin (10 $\mu \mathrm{g} / \mathrm{ml}$ ) diperoleh tingkat perkembangan 1 PN sebesar $4,8 \%$ sedangkan pada dosis $50 \mu \mathrm{g} / \mathrm{ml}(7,3 \%)$ dan dengan dosis $100 \mu \mathrm{g} /$ midiperoleh $1 \mathrm{PN}$ sebesar $5,2 \%$. 


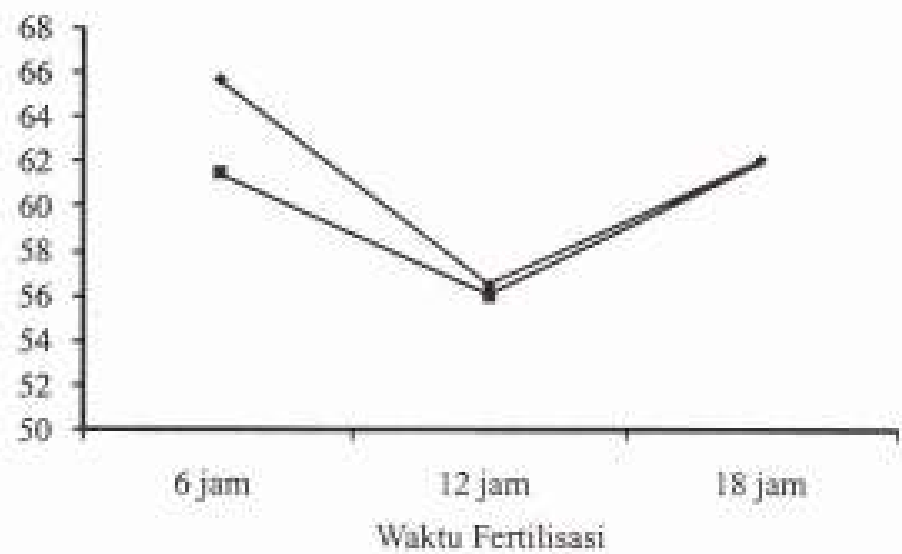

Gambar 2.Persentase fertilisasi in vitro pada waktu fertilisasi dan sistem inkubasi yang berbeda (0 dengan $\mathrm{CO} 25 \%$, $\square$ tanpa $\mathrm{CO}_{2} 5 \%$ )

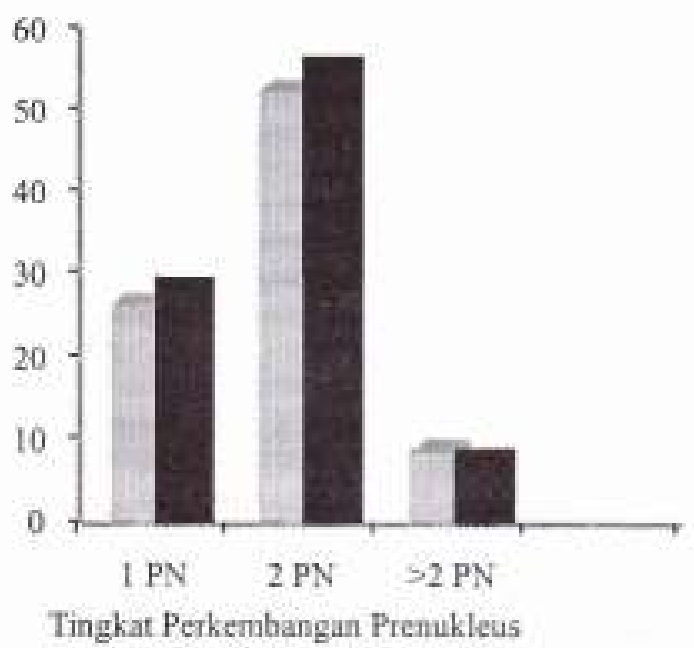

Gambar 3. Tingkat perkembangan pronukleus ( $1 \mathrm{PN}, 2 \mathrm{PN}$, dan $>2 \mathrm{PN}$ ) pada sistem inkubasi yang berbeda (ㅁ dengan $\mathrm{CO} 25 \%$, tanpa CO2 5\%)

Tingkat perkembangan pronukleus 2PN kedua sistem inkubasi yaitu pada sistem inkubasi yang menggunakan $\mathrm{CO} 25 \%$ adalah $52,08 \%$ sedangkan tampa $\mathrm{CO} 25 \%$ sebesar $54,77 \%$. Setelah dianalists sistem inkubasi tidak menunjukkan perbedaan yang nyata $(\mathrm{P}>0,05)$ terhadap tingkat perkem-bangan $2 \mathrm{PN}$.

Hasil penelitian yang hamoir sama diperoleh dari kedua sistem inkubasi yang digunakan yaitu sistem inkubasi CO2 $5 \%$ dan tanpa CO2 $5 \%$. Hal ini disebabkan karena medium yang digunakan pada kedua sistem inkubasi tersebut dapat memberikan kondisi yang optimal pada tingkat perkembangan $2 \mathrm{PN}$.

Pada sistem inkubasi $\mathrm{CO} 2$ 5\% meng-gunakan medium B-O (tanpa Hepes) sedangkan tanpa $\mathrm{CO} 25 \%$ menggunakan medium mB-O (dengan Hepes). Asumsi ini sependapat dengan Visconti et al., (1999) mengemukan bahwa keberhasilart fertilisasi pada medium yang mengandung Hepes dan $\mathrm{NaHCO}_{3}$ hampir sama dengan medium yang mengandung $\mathrm{NaHCO} 3$ tanpa Hepes. 
Hasil penelitian Jaswandi et al., (2004) menunjukkan bahwa penggunaan Hepas dapat menggantikan peran $\mathrm{CO} 25 \%$ dalam produksi embrio. Menurut Triwulanningsih (2002), oosit yang dikultur dalam medium TCM-199 selama 18 jam dalam inkubator $\mathrm{CO} 25 \%$ bersuhu $390 \mathrm{C}$ dapat difertilisasi serta menghasilkan blastosis yang lebih banyak dibandingkan yang dikuitur selama 24 jam.

Hasil penelitian ini menunjukkan bahwa kemampuan perkembangan oosit dari kedua sistem inkubasi pada fertilisasi in vitro hampir sama. Kecenderungan yang sama mungkin disebabkan oleh tingkat penetrasi sperma pada fertilisasi.

Tingkat fertilisasi disebabkan mekanisme oosit yang mencegah masuknya fusi sperma lainnya yang telah dipenetrasi oleh satu sperma. Kegagalan mekanisme ini akan mengakibatkan kejadian polispermia yang berakhir dengan terbentuknya embrio poliploidi, embrio ini akan mengalami perkembangan abnormal dan mati (Hafez dan Hafez, 2000 ). Tingkat perkembangan pronukleus $>2 \mathrm{PN}$ pada berbagai sistem inkubasi yang berbeda yaitu pada sistem inkubasi $\mathrm{CO} 25 \%$ adalah $8,81 \%$ sedangkan pada sistem inkubasi tanpa $\mathrm{CO} 2.5 \%$ sebesar $7,51 \%$. Tingkat perkembangan $>2 \mathrm{PN}$ pada sistem inkubasi $\mathrm{CO} 25 \%$ lebih tinggi dari sistem inkubasi tanpa $\mathrm{CO} 25 \%$. Meskipun terdapat perbedaan tingkat perkembangan pronukleus $>2 \mathrm{PN}$ pada kedua sistem inkubasi namun secara analisis statistik menunjukkan tidak adanya perbedaan yang nyata $(P>0,05)$.

Pada penelitian ini, tingkat perkembangan $>2$ PN tidak jauh berbeda dengan hasil penelitian Jaswandi (2002) mengemukakan bahwa tingkat fertilisasi $>2$ PN pada oosit domba relatif lebih tinggi pada sistem inkubasi $\mathrm{CO} 25 \%$ dalah $9,68 \%$ sedangkan pada sistem inkubasi tanpa $\mathrm{CO}_{2} 5 \%$ sebesar $7,19 \%$.

\section{Tingkat perkembangan pronukleus (PN)}

Terlihat pada Gambar 4 tingkat perkembangan pronukleus IPN terhadap berbagai waktu fertilisasi diperoleh yaitu 6 jam sebanyak $22,03 \% ; 12$ jam sebesar $37,60 \%$ dan 18 jam yaitu $24,23 \%$.

Pada periode inkubasi 12 jam mengalami peningkatan tingkat perkembangan 1 PN sebesar $15,57 \%$, kemudian pada periode inkubasi $18 \mathrm{jam}$ terjadinya penurunan yang cukup drastis yaitu sebesar $25,48 \%$. Dari hasil analisis statistik menunjukkan bahwa waktu fertilisasi sangat berpengaruh nyata $(\mathrm{P}<0,05)$ terhadap perkembangan pronukleus IPN. Setelah dilakukan uji lanjut DMRT, diperoleh tingkat perkembangan pronukleus. IPN yang tertinggi adalah waktu fertilisasi 12 jam yaitu sebesar $36,84 \%$ kemudian diikuti waktu fertilisasi 18 jam adalah $24,41 \%$. Dari hal diatas diasumsikan perpanjangan waktu fertilisasi sampai waktu 18 jam tidak meningkatkan tingkat perkembangan pronukleus IPN pada fertilisasi oosit sapi in vitro. Diperkuat oleh Jaswandi (2002), mengemukakan bahwa perpanjangan periode fertilisasi sampai 24 jam pada domba tidak meningkatkan keberhasilan fertilisasi oosit in vitro.

Tingkat fertilisasi perkembangan pronukleus 2PN pada berbagai waktu fertilisasi diperoleh; pada waktu fertilisasi 6 jam sebanyak $57,42 \%$; 12 jam sebesar $51,70 \%$ sedangkan 18 jam yaitu

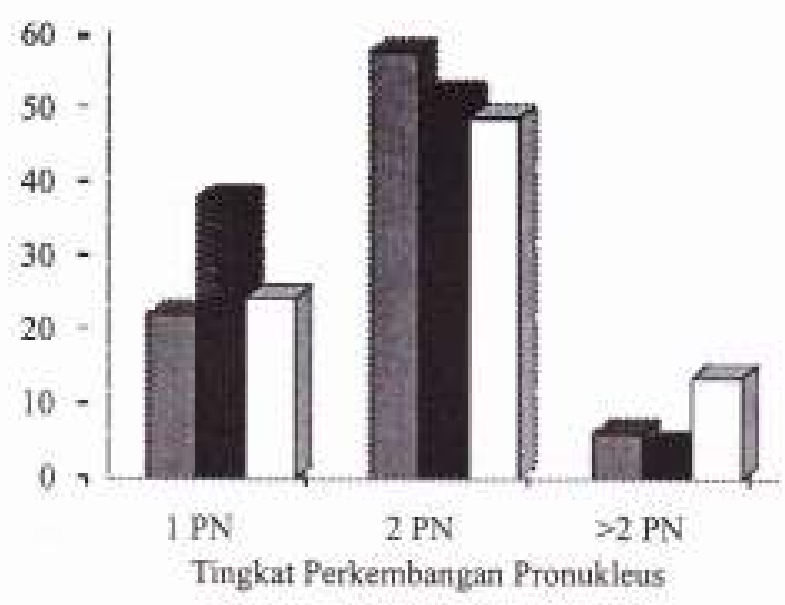

Gambar 4.Perkembungan pronukleus (IPN, $2 \mathrm{PN}_{i}>2 \mathrm{PN}$ ) pada waktu fertilisasi yang berbeda ( $\square 6 \mathrm{jam}, \mathbf{1 2} \mathrm{jam}, \square 18 \mathrm{jam})$ 
sebesar $48,47 \%$. Setelah dianalisis secara statistik menunjukkan bahwa peningkatan waktu fertilisasi tidak menyebabkan pengaruh yang nyata $(\mathrm{P}>0,05)$ terhadap perkembangan pronukleus $2 \mathrm{PN}$.

Menurut Jaswandi (2002) bahwa tingkat fertilisasi yang hampir sama sampai periode inkubasi 24 jam disebabkan oieh oosit yang mempunyai mekanisme yang menghambat masuknya sperma berikutnya bila telah dipenetrasi oleh satu sperma.

Tingkat perkembangan pronukleus $>2$ PN terhadap berbagai waktu fertilisasi diperoleh yaitu; 6 jam yaitu sebesar $6,21 \% ; 12$ jam adalah $4,62 \%$ dan 18 jam adalah $13,66 \%$. Setelah dianalisis secara statistik menunjukkan bahwa waktu fertilisasi tidak adanya perbedaan yang nyata $(\mathrm{P}>0,05)$ terhadap perkembangan pronukleus $>2 \mathrm{PN}$. Peningkatan periode inkubasi dapat menyebabkan penurunan tingkat perkembangan pronukleus $>2 \mathrm{PN}$. Hasil penelitian ini menunjukkan bahwa periode waktu 18 jam efektif digunakan untuk fertilisasi oosit in vitro. Dipertegas oleh Chian et al. (1992), mengemukakan bahwa sperma masih mampu menembus oosit sampai 24 jam setelah di inseminasi tetapi peningkatan tingkat fertilisasi tidak signifikan, dan juga diikuti peningkatan kejadian polispermia yang cukup tinggi. Peningkatan oosit terfertilisasi setelah perpanjangan waktu fertilissi juga diikuti peningkatan oosit yang mempunyai lebih dari dua buah pronuklei ( $>2 \mathrm{PN})$. Kondisi yang kurang menguntungkan dari perpanjangan periode inkubasi adalah peningkatan persentase fertilisasi dapat disebabkan oleh oosit yang mengalami parthenogenesis.

\section{KESIMPULAN}

Berdasarkan hasil dalam penelitian ini, maka dapat ditarik suatu kesimpulan yaitu sistem inkubasi dan waktu fertilisasi tidak berpengaruh terhadap tingkat fertilisasi oosit. Fertilisasi oosit dapat dilakukan pada periode inkubasi $6 \mathrm{jam}, 12$ jam, dan $18 \mathrm{jam}$. Perpanjangan periode fertilisasi sampai 18 jam tidak meningkatkan tingkat fertilisasi

\section{DAFTAR PUSTAKA}

Brackett, B.G, K.A. Zuelke, 1993. Analysis of factors involved in the in vitro production of bovine embryos. Theriogenology 39 : 43-63.
Chian, R.C., H. Nakahara, K. Niwa and Funahashi. 1992. Fertilization and early Cceavage in vitro of aging bovine oocytes after maturation in culture. Theriogenology 37 , $666-672$.

Dode, M.A.N, N.C. Rodovalho, V.G. Ueno and Femandes. 2002. The fffect of sperm preparation and coincubation time on in vitro fertilization of Bos Indicus oocyte. Animal Reproduction Science 69: 15-23.

Gordon, I. 1994. Laboratory Production of Cattle Embrios. Biotechnology in Agricultural Series. CAB. International.

Hafez, B and E.S.E. Hafez. 2000. Reproduction in Farm Animal. 7 th Edition. Lea Febiger. USA.

Herdis, 2000. Pemanfaatan Ovarium sebagai limbah rumah potong hewan untuk meningkatkan populasi ternak melalui teknik fertilisasi in vitro. Jumal Sains dan Teknologi Indonesia 2000, Vol, 2, No. 2 hal. 1-7.

Hunter, R.H.F. 1995. Fisiologi dan Teknologi Reproduksi Hewan Betina Domestik (Peterjemah Harya Putra). Penerbit ITB, Bandung.

Jaswandi, Z. Udin dan M. Mundana. 2004. Pengembangan Sistem Kultur Tanpa $\mathrm{CO} 2$ dalam Produksi Embrio Secara In Vitro. Laporan Hibah Bersaing XI. Universitas Andalas.

Jaswandi. 2003. Kualitas dan Angka Maturasi In Vitro Oosit Domba Pada Berbagai Suhu dan Waktu Penyimpanan Ovarium. Laporan Penelitian Dosen Muda. BBI, Dikti. Universitas Andalas.

Jaswandi. 2002. Penggunaan Hepes dan Butiran Efervesen dalam Sistem Inkubasi Pada Produksi Embrio Domba Secara In Vitro. Disertasi Program Pascasarjana IPB, Bogor.

Jiang, H.S. W.L. Wong, K.H. Lu, I Gordon, and Polge, C. 1991. Roles of cell monolayers in the coculture of in vitro fertization bovine embryos. J. Theriogenology, 35 , 216.

Pinyopummintr, T and B.D. Bavister. 1995. Optimum gas atmsphere for in vitro fertilization of bovine oocytes. Theriogenology $44,471-477$. 
Rehman, N., A.R. Collums, T.K. Suh and R.W. W Junior. 1994. Effects sperm exposure time on in vitro fertilization and embryo development of bovine oocytes matured in vitro. Theriogenology $41: 1447-1465$.

Thompson, J.G 1996. Defining the requirement for bovine embrio culture. Theriogenology 45:97-100.

Triwulanningsih, E. 2002. Pengaruh Produksi Sapi Lokal In Vitro dengan Modifikasi Waktu dan Suhu Pada Medium Maturasi Yang Diperkaya dengan FSH dan Estradiol
17 B. Disertasi Program Pascasarjana Institut Pertanian Bogor, Bogor.

Shamsuddin, M., B. Larsson and H. RodriquezMartinez, 1993. Maturation related change in bovine oocytes under different culture conditions. Animal Reproduction Science $31,49-60$.

Steel, R.G.D and Torrie. 1995. Prinsip dan Prosedur Statistika Suatu Pendekatan Biometrik. Alih Bahasa B. Sumantn, Edition kedua, Cetakan 2. PencrbitPT. Gramedia Pustaka Utama, Jakarta. 